\title{
Consequences and mitigation of saltwater intrusion induced by short-circuiting during aquifer storage and recovery in a coastal subsurface
}

\author{
Koen Gerardus Zuurbier ${ }^{1,2}$ and Pieter Jan Stuyfzand ${ }^{1,2}$ \\ ${ }^{1}$ KWR Watercycle Research Institute, Groningenhaven 7, 3433 PE Nieuwegein, the Netherlands \\ ${ }^{2}$ Technical University Delft, Faculty of Civil Engineering, P.O. Box 5048, 2600 GA Delft, the Netherlands \\ Correspondence to: Koen Gerardus Zuurbier (koen.zuurbier@kwrwater.nl) \\ Received: 11 July 2016 - Discussion started: 25 July 2016 \\ Revised: 29 December 2016 - Accepted: 14 January 2017 - Published: 27 February 2017
}

\begin{abstract}
Coastal aquifers and the deeper subsurface are increasingly exploited. The accompanying perforation of the subsurface for those purposes has increased the risk of shortcircuiting of originally separated aquifers. This study shows how this short-circuiting negatively impacts the freshwater recovery efficiency (RE) during aquifer storage and recovery (ASR) in coastal aquifers. ASR was applied in a shallow saltwater aquifer overlying a deeper, confined saltwater aquifer, which was targeted for seasonal aquifer thermal energy storage (ATES). Although both aquifers were considered properly separated (i.e., a continuous clay layer prevented rapid groundwater flow between both aquifers), intrusion of deeper saltwater into the shallower aquifer quickly terminated the freshwater recovery. The presumable pathway was a nearby ATES borehole. This finding was supported by field measurements, hydrochemical analyses, and variable-density solute transport modeling (SEAWAT version 4; Langevin et al., 2007). The potentially rapid short-circuiting during storage and recovery can reduce the RE of ASR to null. When limited mixing with ambient groundwater is allowed, a linear RE decrease by short-circuiting with increasing distance from the ASR well within the radius of the injected ASR bubble was observed. Interception of deep short-circuiting water can mitigate the observed RE decrease, although complete compensation of the RE decrease will generally be unattainable. Brackish water upconing from the underlying aquitard towards the shallow recovery wells of the ASR system with multiple partially penetrating wells (MPPW-ASR) was observed. This "leakage" may lead to a lower recovery efficiency than based on current ASR performance estimations.
\end{abstract}

\section{Introduction}

Confined and semi-confined aquifers are increasingly being used for storm water and (Ferguson, 1990), brine disposal (Stuyfzand and Raat, 2010; Tsang et al., 2008) and storage of freshwater (aquifer storage and recovery or ASR; Pyne, 2005), heat (aquifer thermal energy storage or ATES; Bonte et al., 2011a), and $\mathrm{CO}_{2}$ (Steeneveldt et al., 2006). Additionally, they are perforated for exploitation of deep fossil and geothermal energy and traditionally used for abstraction of drinking and irrigation water. The increased use of the subsurface can lead to interference among aquifer storage systems (e.g., Bakr et al., 2013) or affect the groundwater quality (Bonte et al., 2011b, 2013; Zuurbier et al., 2013b). These consequences form relevant fields of current and future research.

The perforation of aquifers and aquitards accompanying the subsurface activities imposes an additional risk by the potential creation of hydraulic connections ("conduits") between originally separated aquifers or aquifers and surface waters. This risk is plausible, as estimations indicate that about two-thirds of the wells worldwide may be improperly sealed (Morris et al., 2003), although the attention for this potential risk is limited (Chesnaux, 2012). Additionally, many of the new concepts to use the subsurface (e.g., ATES, ASR, brine disposal) require injection via wells, which may cause fractures, even when the annulus is initially properly sealed, by exceedance of the maximum-permissible injection pressure (Hubber and Willis, 1972; Olsthoorn, 1982). The soil fractures are undesirable for most groundwater wells in the 
relatively shallow subsurface, since they create new connections between originally separated aquifers.

The resulting short-circuiting or leakage process has been studied at laboratory (Chesnaux and Chapuis, 2007) and field scale (Jiménez-Martínez et al., 2011; Richard et al., 2014), and for deep geological $\mathrm{CO}_{2}$ storage (Gasda et al., 2008). Santi et al. (2006) evaluated tools to investigate cross-contamination of aquifers. Chesnaux et al. (2012) used numerical simulations of theoretical cases to demonstrate the consequences of pumping tests and hydrochemistry of hydraulic connections between granular and fractured-rock aquifers, which clearly demonstrated the significant hydrochemical cross-contamination when short-circuiting aquifers have a distinct chemical composition. The impact of shortcircuiting on ASR has not been evaluated to date. However, reliably confined aquifers are vital to successfully store energy (Bonte et al., 2011a) and freshwater (Maliva et al., 2016; Maliva and Missimer, 2010; Missimer et al., 2002; Pyne, 2005; Zuurbier et al., 2013a) to bridge periods of surplus and demand, as inter-aquifer leakage may result in a loss of freshwater or undesirable admixing groundwater with a poorer quality, and therefore a reduced ASR performance. Furthermore, although the risks of short-circuiting by perturbation are acknowledged by scientists, it seems that the practical and regulatory communities are less aware (Chesnaux, 2012). This is underlined by the fact that certification for mechanical drilling (applied since the Industrial Revolution) in the Netherlands was not obligatory before 2011 (Stichting Infrastructuur Kwaliteitsborging Bodembeheer, 2013a), while for the subsurface design and operation of ATES systems (> 1500 systems since the 1990s; Bonte et al., 2011a; CBS, 2013), obligatory certification has only been enforced since early 2014 (Stichting Infrastructuur Kwaliteitsborging Bodembeheer, 2013b).

The lack of proper design and regulation of subsurface activities using wells can be partly caused by the lack of clear field examples of how well-intentioned use of the subsurface for sustainability purposes can fail thanks to earlier activities underground. This lack can be caused by the fact that shortcircuiting may not be easy to observe (Santi et al., 2006), or because failing or disappointing projects often do not make it to public or scientific reports. Therefore, we present in this study how short-circuiting via a deeper borehole led to failure of freshwater recovery during ASR in a coastal aquifer. The objective of this paper is to demonstrate and characterize the potential consequences of perturbations for coastal ASR systems. Additionally, the use of deep interception of saltwater to improve shallow recovery of freshwater upon ASR was assessed. The Westland ASR site in the coastal area of the Netherlands served as a demonstration and reference case.
Table 1. Depth of the various well screens.

\begin{tabular}{lrr}
\hline Well screen & $\begin{array}{r}\text { Top } \\
\text { (m b.s.l.) }\end{array}$ & $\begin{array}{r}\text { Bottom } \\
\text { (m b.s.l. })\end{array}$ \\
\hline AW1.1 + AW2.1 & 23.1 & 26.6 \\
AW1.2 + AW2.2 & 27.6 & 30.6 \\
AW1.3 + AW2.3 & 31.6 & 36.4 \\
ATES K3-b & 53 & 61 \\
& 80 & 85 \\
\hline
\end{tabular}

\section{Methods}

\subsection{Setup Westland ASR system and pilot}

The Westland ASR system is installed to inject the rainwater surplus of $270000 \mathrm{~m}^{2}$ of greenhouse roof in a local shallow aquifer (23 to 37 meters below sea level, mb.s.l.; surface level $=0.5$ meter above sea level, $\mathrm{ma.s.1}$.) with negligible lateral displacement (Zuurbier et al., 2013a) for recovery in times of demand. For this purpose, two multiple partially penetrating wells (MPPW) were installed (Fig. 1), such that water can be injected preferably at the aquifer base, and recovered at the aquifer top in order to increase the recovery (Zuurbier et al., 2014). Due to the limited space available at the greenhouse site, the ASR well was installed close to an existing ATES well, injecting (in winters) and abstracting (in summers) cold water of about $5^{\circ} \mathrm{C}$. All ASR (AW1 and AW2, installed in 2012) and ATES (K3-a, installed in 2006 and replaced by $\mathrm{K} 3-\mathrm{b}$ at $3 \mathrm{~m}$ from $\mathrm{AW} 1$ and $7 \mathrm{~m}$ from AW2 in 2008) wells were installed using reverse-circulation rotary drilling, while the monitoring wells (MW1-5, Fig. 2) were installed using bailer drilling. Bentonite clay was applied to seal the ASR well (type: Micolite300) and ATES well K3 (Micolite000 and Micolite300). The depth of the well screens is shown in Table 1. The monitoring wells were installed at $5 \mathrm{~m}$ (MW1), $15 \mathrm{~m}$ (MW2), $30 \mathrm{~m}$ (MW3), $32 \mathrm{~m}$ (MW4), and $60 \mathrm{~m}$ (MW5).

The ASR wells used a $3.2 \mathrm{~m}$ high standpipe to provide injection pressure, whereas the ATES well used a pump to meet the designed injection rate of $75 \mathrm{~m}^{3} \mathrm{~h}^{-1}$. The maximum $\mathrm{Cl}$ concentration in the recovered water accepted at the site is $50 \mathrm{mg} \mathrm{L}^{-1}$. The ASR operation was relatively "dynamic" due to the incorporation of the ASR system in the water supply of a greenhouse; injection occurred in times of high levels in the aboveground rainwater reservoirs, whereas recovery occurred when low reservoir levels were observed. This led to the general ASR cycles as presented in Table 2.

\subsection{Detailed hydrogeological characterization based on local drillings}

The target aquifer for ASR (Aquifer 1) was found to be $14 \mathrm{~m}$ thick and consists of coarse fluvial sands (average grain size: $400 \mu \mathrm{m}$; see Fig. 3 ) with a hydraulic conductivity $(K)$ derived 


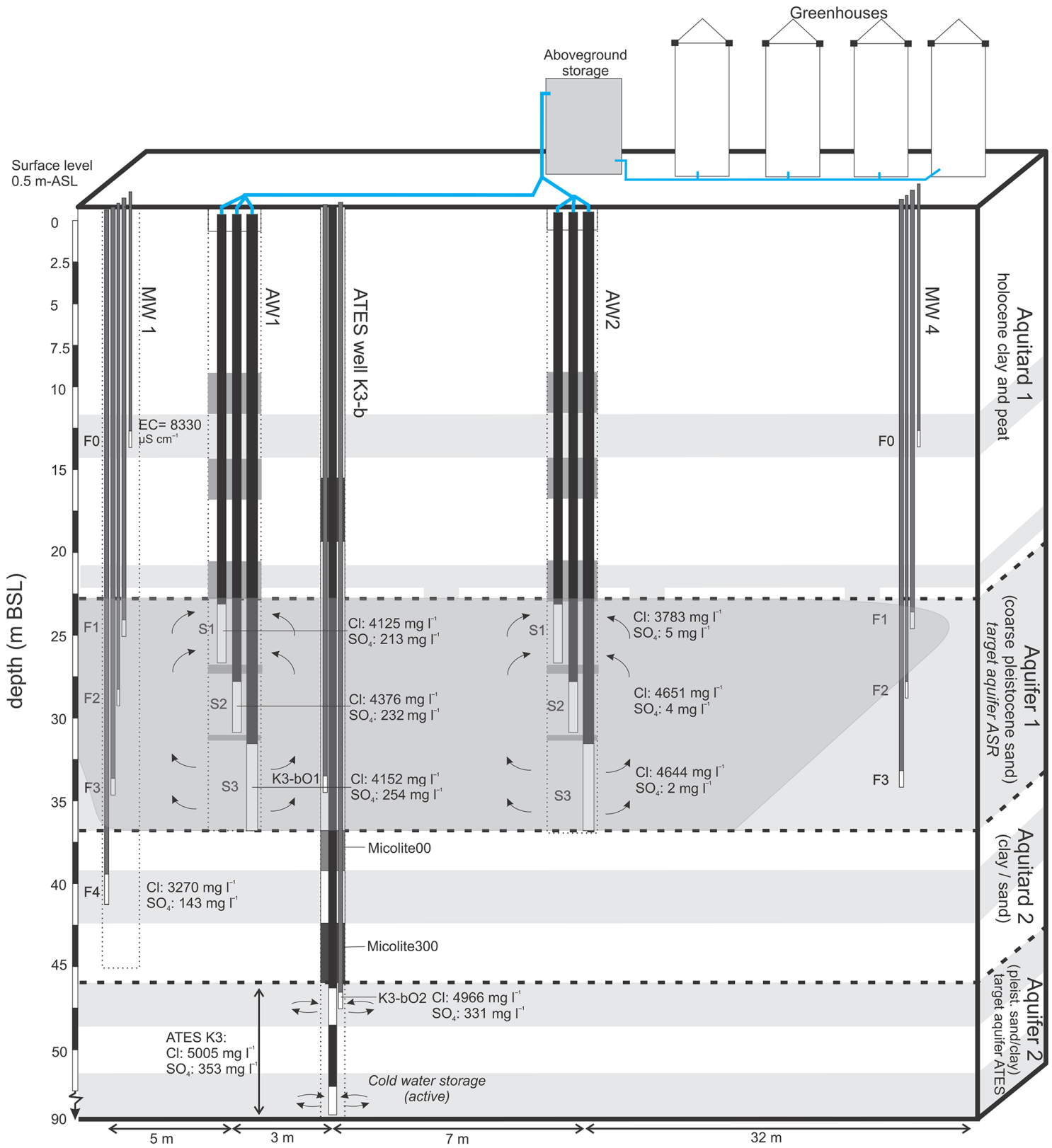

Figure 1. Cross section of the Westland ASR site to schematize the geology, ASR wells, ATES well, and the typical hydrochemical composition of the native groundwater. Horizontal distances not to scale.

Table 2. Summary of the ASR operation.

\begin{tabular}{lll}
\hline Stage & Date & Wells \\
\hline Injection cycle 1.1 & 12 December (2012)-11 January (2013) & AW1 + AW2 \\
Recovery cycle 1.1 & 11 January-28 January (2013) & AW1.1 + AW2.1 \\
Injection cycle 1.2 & 4 February-8 February (2013) & AW1 + AW2 \\
Recovery cycle 1.2 & 5 March-11 March (2013) & AW2.1+ AW2.2 \\
Injection cycle 2 & 11 September (2013)-5 March (2014) & AW1 + AW2 \\
Recovery cycle 2 & 5 March-24 June (2014) & AW2.1+ AW2.2
\end{tabular}




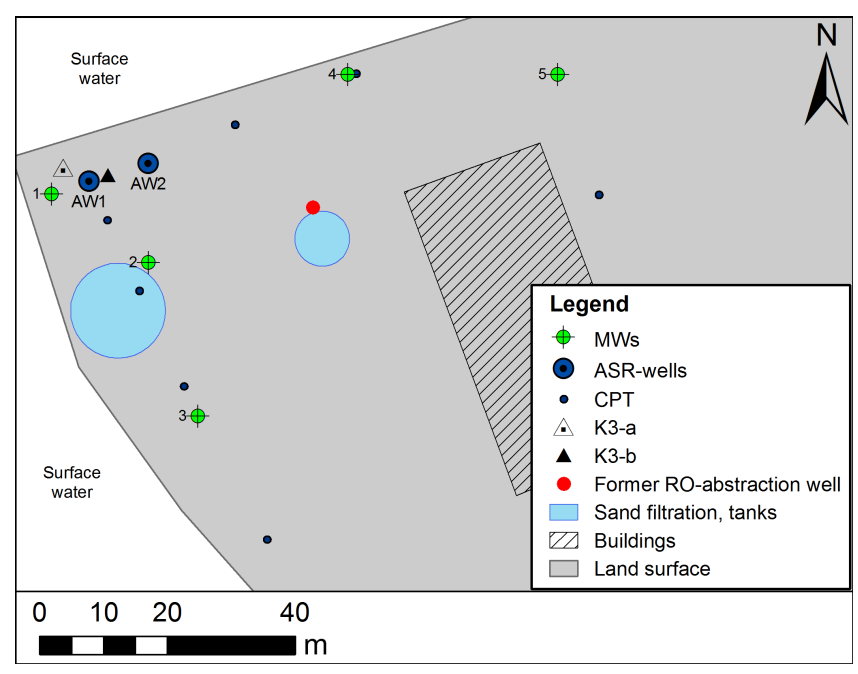

Figure 2. Locations of ASR (AW), ATES, and monitoring wells (MW).

from head responses at the monitoring wells upon pumping of $30-100 \mathrm{~m} \mathrm{~d}^{-1}$. Aquifer 2 (target aquifer for ATES) has a thickness of more than $40 \mathrm{~m}$, but is separated in two parts at the ATES well K3-b by a $20 \mathrm{~m}$ thick layer clayey sand and clay. A blind section was installed in this interval, and the borehole was backfilled with coarse gravel in this section. The $K$ value of the fine sands in Aquifer 2 derived from a pumping test at approximately $500 \mathrm{~m}$ from the ASR well is 10 to $12 \mathrm{~m} \mathrm{~d}^{-1}$ and is in line with the estimated $K$ value from grain size distribution (Mos Grondmechanica, 2006). The effective screen length of K3-b in this aquifer is only 8 and $5 \mathrm{~m}$ (Table 1).

The groundwater is typically saline, with observed $\mathrm{Cl}$ concentrations ranging from 3793 to $4651 \mathrm{mg} \mathrm{L}^{-1}$ in Aquifer 1 and approximately $5000 \mathrm{mg} \mathrm{L}^{-1}$ in Aquifer 2 (see also Fig. 1). This means that with the accepted $\mathrm{Cl}$ concentrations during recovery, only around $1 \%$ of admixed ambient groundwater is allowed. A sand layer in Aquitard 2 contains remnant fresher water $\left(\mathrm{Cl}=3270 \mathrm{mg} \mathrm{L}^{-1}\right)$. $\mathrm{SO}_{4}$ is a useful tracer to identify the saltwater from Aquifers 1 and 2: it is virtually absent in Aquifer 1 (presumably younger groundwater, infiltrated when the Holocene cover was already thick), whereas it is high in Aquifer 2 (older water, infiltrated through a thinner clay cover which limited $\mathrm{SO}_{4}$ reduction; see Stuyfzand, 1993, for more details): 300 to $400 \mathrm{mg} \mathrm{L}^{-1} \mathrm{SO}_{4}$.

\subsection{Monitoring during Westland ASR cycle testing}

All ASR and monitoring well screens were sampled prior to ASR operation (November and December, 2012). MW1 and MW2 were sampled with a high frequency during the first breakthrough of the injection water at MW1 (December 2012, January 2013), while all wells were sampled on a monthly basis (Table 3). In all, 3 times the volume of the well casing was removed and stable field parameters were attained prior to sampling. The injection water was sampled regularly during injection phases. All samples were analyzed in the field in a flow-through cell for electrical conductivity (EC) (GMH 3410, Greisinger, Germany), $\mathrm{pH}$ and temperature (Hanna 9126, Hanna Instruments, USA), and dissolved oxygen (Odeon Optod, Neotek-Ponsel, France). Samples for alkalinity determination within 1 day after sampling on the Titralab 840 (Radiometer Analytical, France) were stored in a $250 \mathrm{~mL}$ container. Samples for further hydrochemical analysis were passed over a $0.45 \mu \mathrm{m}$ cellulose acetate membrane (Whatman FP-30, UK) in the field and stored in two $10 \mathrm{~mL}$ plastic vials, of which one was acidified with $100 \mu \mathrm{L}$ $65 \% \mathrm{HNO}_{3}$ (Suprapur, Merck International) for analysis of cations (Na, K, Ca, Mg, Mn, Fe, S, Si, P, and trace elements) using ICP-OES (Varian 730-ES ICP OES, Agilent Technologies, USA). The second $10 \mathrm{~mL}$ vial was used for analysis of $\mathrm{F}, \mathrm{Cl}, \mathrm{NO}_{2}, \mathrm{Br}, \mathrm{NO}_{3}, \mathrm{PO}_{4}$, and $\mathrm{SO}_{4}$ using the Dionex DX-120 IC (Thermo Fischer Scientific Inc., USA), and $\mathrm{NH}_{4}$ using the LabMedics Aquakem 250 (Stockport, UK). All samples were cooled to $4{ }^{\circ} \mathrm{C}$ and stored dark immediately after sampling.

Combined electrical conductivity, temperature, and pressure transducers (CTD) divers (Schlumberger Water Services, Delft, the Netherlands) were used for continuous monitoring of conductivity, temperature, and pressure in the target aquifer at MW1 and MW2. Calibrated, electronic water meters were coupled to the programmable logic controller (PLC) of the ASR system to record the operation per well screen.

\subsection{Setup Westland ASR groundwater transport model}

Groundwater transport modeling was executed to validate the added value of the MPPW setup under the local conditions. In the later stage of the research, the groundwater transport model was used to test potential pathways for deeper groundwater to enter the target aquifer and explore the characteristics of a potential conduit via scenario modeling. Correction for groundwater densities in the flow modeling was vital, due to significant contrast between the aquifer's groundwater and the injected rainwater. In order to incorporate variable density flow and the transport multiple species, SEAWAT version 4 (Langevin et al., 2007) was used with PMWIN 8 (Chiang, 2012) to simulate the ASR operation. A half-domain was modeled to reduce computer runtimes (Fig. 4). Cells of $1 \times 1 \mathrm{~m}$ were designated to an area of $20 \times 20 \mathrm{~m}$ around the ASR wells. The cell size increased to $2.5 \mathrm{~m} \times 2.5 \mathrm{~m}(30 \mathrm{~m} \times 40 \mathrm{~m}$ around the well $)$ and was then gradually increased to a maximal cell size of $200 \mathrm{~m} \times 200 \mathrm{~m}$ at $500 \mathrm{~m}$ from the ASR wells. The pumping rate of each well screen was distributed over the models cells with the well package based on the transmissivity (thickness $\times$ hydraulic conductivity) of each cell. The third-order total-variationdiminishing (TVD) scheme (Leonard, 1988) was used to 
Table 3. Sampling rounds at the Westland ASR site (2012-2014). "IN" is injection water.

\begin{tabular}{ll}
\hline Well(s) & Date \\
\hline K3-b, K3-bO2 & 22 August 2012 \\
AW1, AW2 & 6 November 2012 \\
MW1-MW5 & 5 December 2012 \\
MW1 & 14 December 2012 \\
MW1 & 17 December 2012 \\
MW1, MW2, IN & 18 December 2012 \\
MW1, MW2 & 20 December 2012 \\
MW1, MW2, IN & 21 December 2012 \\
MW1, MW2 & 24 December 2012 \\
MW1, MW2 & 27 December 2012 \\
MW1, MW2 & 31 December 2012 \\
MW1, MW2, MW4 & 4 January 2013 \\
MW1, MW2, IN & 11 January 2013 \\
AW1, AW2 & 14 January 2013 \\
MW1, MW2, MW4 & 17 January 2013 \\
AW1, AW2 & 25 January 2013 \\
MW1, MW2, MW4, IN & 12 February 2013 \\
AW1, AW2 & 8, 11, 19 March 2013; \\
& 8 April 2013; 11, 14, 17, \\
21, 28 March 2014; & 2, 15, 17, 28 April 2014; \\
K3-bO1 & 5, 22 May, 2 June 2014 \\
11 March, 8 April 2013; & 17 September 2013; Octo- \\
bW1, MW2, MW3, MW4 2013; 6 November 2013; & 11 December 2013 14 Jan- \\
& uary 2014; 19 February 2014; \\
& 21, 28 March 2014; \\
& 8, 28 April 2014; 5 May 2014 \\
\hline & \\
&
\end{tabular}

model advection and maintain the sharp edges of the freshwater bubble by limiting numerical dispersion.

Equal constant heads were imposed at two side boundaries of the aquifers, the top of the model (controlled by drainage) and at the base of the model. No-flow boundaries were given to the other two side boundaries of the model. Initial Cl concentrations were based on the results of the reference groundwater sampling at MW1. $\mathrm{SO}_{4}$ concentrations in Aquifer 1 were based on MW2, since these concentrations were considered most representative for the field site; this well was close to the ASR wells, but not potentially disturbed by the ATES or ASR wells. For Aquifer 2, the concentrations found at ATES well K3-b (bulk) and the observation well K3-bO.1 were used (see Fig. 1). The density of the groundwater was based on the $\mathrm{Cl}$ concentration using

$$
\rho_{w}=1000+0.00134 \times \mathrm{Cl}\left(\mathrm{mgL}^{-1}\right) .
$$

Density and viscosity were not corrected for temperature, as all temperatures (background groundwater, injected ASR water, and injected ATES water) were in the range of 8 to
$12{ }^{\circ} \mathrm{C}$ and should not significantly impact the flow pattern (Ma and Zheng, 2010). A longitudinal dispersivity of $0.1 \mathrm{~m}$ was derived from the freshwater breakthrough at MW1 and was applied to the whole model domain. Constant heads were based on the local drainage level (top model layer) and the observed heads in the aquifer. The regional hydraulic gradient was derived from regional groundwater heads (TNO, 1995). Further details are given in Table 4.

The recorded pumping rates of the ASR wells and the ATES K3-b well during two ASR cycles were incorporated in the SEAWAT model. The ASR operation was modeled with a properly sealed and an unsealed ATES borehole. In the latter case, a hydraulic conductivity $(K)$ of $1000 \mathrm{~m} \mathrm{~d}^{-1}$ was given to the cells $(1.0 \mathrm{~m} \times 1.0 \mathrm{~m})$ in Aquifer 1, Aquitard 2, and Aquifer 2 at the location of the ATES pumping well to force a significant borehole leakage. This $K$ was considered realistic since apart from filter sand around the well screen; the borehole was backfilled with gravel with a grain size of 2 to $5 \mathrm{~mm}$. In later scenarios, the ATES well was moved towards the fringe of the ASR well stepwise ( $10 \mathrm{~m}$ further away from AW1 in each scenario), after which Cycle 2 was simulated again. This was to examine the impact of borehole leakages at various distances from the ASR wells.

\subsection{The maximal recovery efficiency with and without leakage at the Westland ASR site.}

The collected data on the aquifer characteristics in the SEAWAT groundwater model were used to analyze the future performance of the MPPW-ASR system for the current (with leakage) and a "normal field site" (without leakage from deeper aquifers via a perturbation, or after sealing of the perturbation). The SEAWAT model was used to simulate three consecutive ASR cycles with the representative operational characteristics from Table 5 for the Westland site (Zuurbier et al., 2012). Once the recovered $\mathrm{Cl}$ concentration exceeded $50 \mathrm{mg} \mathrm{L}^{-1}$, the model was stopped, and the length of the stress period with recovery was adjusted, such that no water with $\mathrm{Cl}>50 \mathrm{mg} \mathrm{L}^{-1}$ was recovered. Subsequently the model was run again after adding another cycle.

\section{Results}

\subsection{Cycle 1 (2012-2013): first identification of borehole leakage}

The first ASR cycle started in December 2012. The first recovery started halfway January 2013. Despite the abstraction with only the shallow wells of the MPPW, a rapid and severe salinization was found within the first days of recovery, after injecting freshwater for about 1 month (Fig. 5). It was expected that due to mixing and buoyancy effects during ASR, MW2 would salinize first, followed by MW1, and finally the ASR wells (AW1 and AW2) towards the end of the recovery phase, with each time the deepest well screens 
Table 4. Hydrogeological properties of the geological layers in the Westland SEAWAT model.

\begin{tabular}{lrrrrrrrr}
\hline Geological layer & $\begin{array}{r}\text { Model } \\
\text { layers }\end{array}$ & $\begin{array}{r}\text { Base } \\
(\mathrm{m} \text { b.s.l. })\end{array}$ & $\begin{array}{r}K_{h} \\
\left(\mathrm{~m} \mathrm{~d}^{-1}\right)\end{array}$ & $\begin{array}{r}K_{v} \\
\left(\mathrm{~m} \mathrm{~d}^{-1}\right)\end{array}$ & $\begin{array}{r}S_{S} \\
\left(\mathrm{~m}^{-1}\right)\end{array}$ & $\begin{array}{r}n \\
(-)\end{array}$ & $\begin{array}{r}\text { Initial C } \\
\left(\mathrm{mg} \mathrm{L}^{-1} \mathrm{Cl}^{2}\right)\end{array}$ & $\begin{array}{r}\text { Initial C } \\
\left(\mathrm{mg} \mathrm{L}^{-1} \mathrm{SO}_{4}\right)\end{array}$ \\
\hline Aquitard 1 & 6 & 22.3 & $0.2-1$ & $0.002-0.01$ & $10^{-4}$ & 0.2 & $2000-3000$ & 4 \\
Aquifer 1 & 12 & 33.7 & 35 & 35 & $10^{-7}$ & 0.3 & $4000-4800$ & 4 \\
& 3 & 36.4 & 100 & 100 & & & 3200 & 160 \\
Aquitard 2 (clay-sand) & 8 & 47.5 & $0.05-10$ & $0.0005-10$ & $10^{-4}$ & $0.2-0.3$ & $331-375$ \\
Aquifer 2 & 6 & 96 & 12 & 12 & $10^{-6}$ & 0.3 & $4100-7900$ & 3300 \\
\hline
\end{tabular}

Table 5. Setup of the modeled, representative ASR cycle for the Westland subsurface without short-circuiting of deeper saltwater.

\begin{tabular}{lll}
\hline Stage & Duration & Pumping rate \\
\hline Injection & 120 days & $60000 / 120=500 \mathrm{~m}^{3} \mathrm{~d}^{-1}$ \\
Storage & 30 days & $0 \mathrm{~m}^{3} \mathrm{~d}^{-1}$ \\
Recovery & 120 days & $-60000 / 120=-500 \mathrm{~m}^{3} \mathrm{~d}^{-1}$ \\
Idle & 65 days* & $0 \mathrm{~m}^{3} \mathrm{~d}^{-1}$ \\
\hline
\end{tabular}

* Longer when early salinization occurred during recovery.

salinizing first. This salinization would then be caused by the replacement of freshwater by ambient groundwater (very low- $\mathrm{SO}_{4}$ concentrations) from the same aquifer (Ward et al., 2009). Remarkably, the salinization at AW1 preceded salinization of the monitoring wells situated further from the ASR wells (MW1, MW2). Furthermore, $\mathrm{SO}_{4}$ concentrations (up to $>50 \mathrm{mg} \mathrm{L}^{-1}$ ) were found in the recovered water, which could not be explained by the $\mathrm{SO}_{4}$ concentration attained by pyrite oxidation by oxygen and nitrate present in the injection water (Zuurbier et al., 2016), which would result in $\mathrm{SO}_{4}$ concentrations of less than $15 \mathrm{mg} \mathrm{L}^{-1}$.

The SEAWAT model underlined that tilting of the freshwater-saltwater interfaces at the fringe of the ASR bubble did not cause the early salinization observed, as this would have led to a much later salinization (Fig. 6) without enrichment of $\mathrm{SO}_{4}$ (other than be pyrite oxidation), even if the recovery period was extended (results not shown). When the leaky borehole was incorporated in the model (by assigning $K=1000$ in a $1 \mathrm{~m} \times 1 \mathrm{~m}$ column at the location of the current ATES well), it was able to introduce the early recovery of deep ( $\mathrm{SO}_{4}$-rich) water (Fig. 7). Other scenarios that were tested, but unable to improve the simulation of the observed $\mathrm{SO}_{4}$ trends, were leakage via the former ATES K3-a well further from the ASR wells (arrival of $\mathrm{SO}_{4}$ too late), a high- $K_{v}$ borehole $\left(2000 \mathrm{~m} \mathrm{~d}^{-1}\right.$; arrival too early, flux too high), a low-K borehole ( $500 \mathrm{~m} \mathrm{~d}^{-1}$; arrival too late, flux too low), a vertical anisotropy in the aquifers $\left(K_{h} / K_{z}=2\right.$; arrival too early, flux too high), and omission of the deep cold water abstraction from Aquifer 2 via the ATES well in Aquifer 2 ( $\mathrm{SO}_{4}$; flux too high).
The hydrochemical observations and model outcomes of Cycle 1 indicated that the source of the early salinization was the intrusion of saltwater from Aquifer 2. Considering the lithology, thickness, and continuity of Aquitard 2 (confirmed by grain size analyses and cone penetrating tests on the site), leakage via natural pathways through this separating layer was unlikely. According to the rate and sequence of salinization, the leakage could well be situated at the ATES K3-b well close to AW1.

\subsection{Cycle 2 (2013-2014): improving the ASR operation}

Cycle 2 started with the injection of $66178 \mathrm{~m}^{3}$ of rainwater using both ASR wells between September 2013 and March 2014, which was followed by recovery solely at the downstream AW2 (start: 5 March 2014). A rapid salinization by $\mathrm{SO}_{4}$-rich saltwater was again observed (Fig. 8) and the recovery was terminated after 26 days (21 March 2014) after recovering no more than $2500 \mathrm{~m}^{3}$. During this cycle, a monitoring well present in the gravel pack of the ATES K3-b well (coded K3-bO1; a $1 \mathrm{~m}$ well screen at $33 \mathrm{~m}$ b.s.l., Fig. 1) was also sampled and equipped with a CTD diver and continuously pumped with a rate of $1 \mathrm{~m}^{3} \mathrm{~h}^{-1}$, unraveling high ECs and presence of $\mathrm{SO}_{4}$-rich saltwater from the deeper aquifer in the center of the injected freshwater body (Fig. 8). This presence of intruding deep saltwater was also found at MW1S3 (5 m from the ASR wells) as a consequence of displacement while re-injecting part of the abstracted freshwater from the shallow AW2S1 wells screen at the deeper AW2S3 well screen and density-driven flow (spreading over the base of the aquifer). The observed $\mathrm{Cl}$ concentration $\left(268 \mathrm{mg} \mathrm{L}^{-1}\right)$ on 2 April 2014 at MW1S4 (situated in Aquitard 2 at $5 \mathrm{~m}$ from AW1) was significantly lower than at MW1S3 (2528 $\mathrm{mg} \mathrm{L}^{-1}$ ) and $\mathrm{K} 3-\mathrm{bO} 1$ (3341 $\mathrm{mg} \mathrm{L}^{-1}$ ), indicating that salinization of the shallow target aquifer (Aquifer 1) preceded salinization of Aquitard 2.

In order to re-enable recovery of freshwater, the deepest wells of the MPPWs (AW1S3 and AW2S3) were transformed to interception wells or "Freshkeepers" (Stuyfzand and Raat, 2010; Van Ginkel et al., 2014), abstracting the intruding saltwater and injecting this in a deep injection well in Aquifer 2 at of distance $200 \mathrm{~m}$ from the ASR site. This way, an acceptable water quality $\left(\mathrm{Cl}<50 \mathrm{mg} \mathrm{L}^{-1}\right)$ could be recovered 


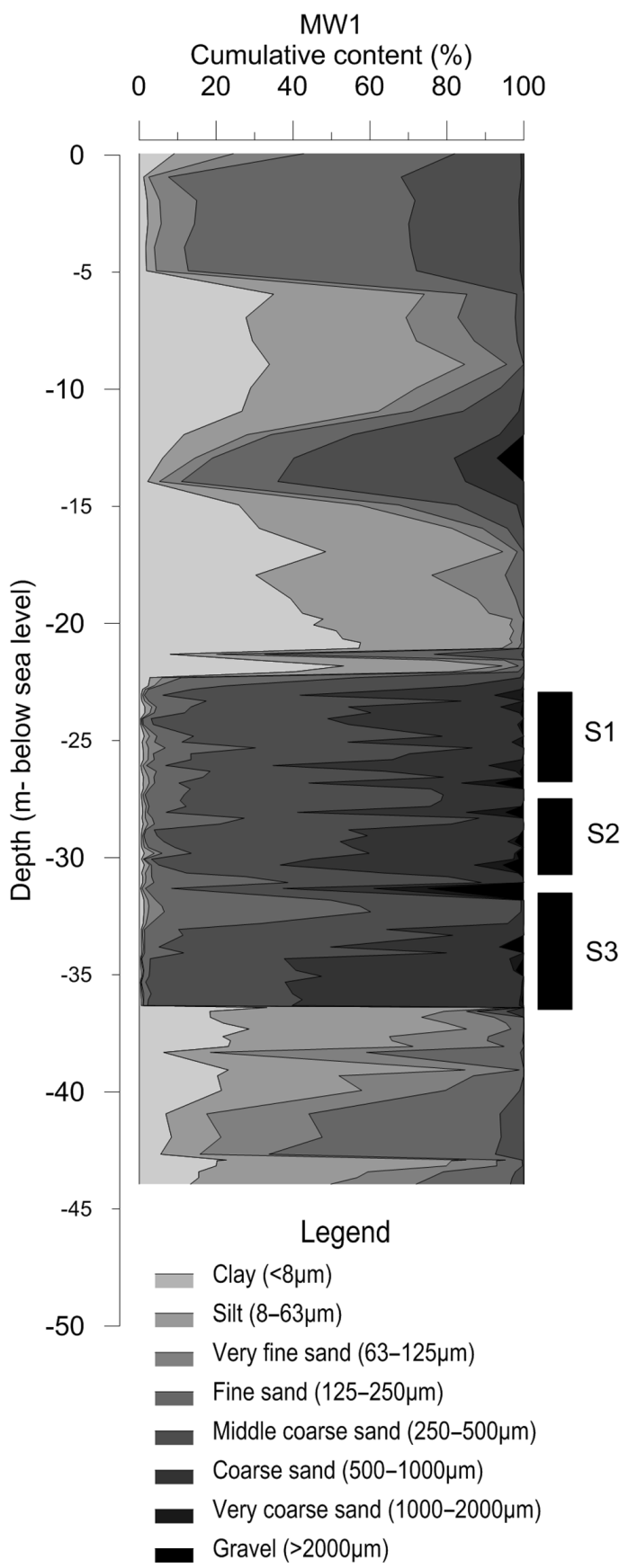

Figure 3. Cumulative grain size contents observed at MW1 (at $5 \mathrm{~m}$ from ASR well 1) in this study. S1-S3 mark the depth intervals of the ASR well screens.

at AW2S1 and AW1S2 again (from 15 April onwards). As a consequence, the deeper segments of the target aquifer (S3 levels, Fig. 8b, c, d) first freshened, followed by again salinization as recovery proceeded. Saline water was continuously observed at K3-bO1, indicating that leakage via the K3-b borehole continued. After recovery of in total $12324 \mathrm{~m}^{3}$ of practically unmixed rainwater ( $18.6 \%$ of the injected water),

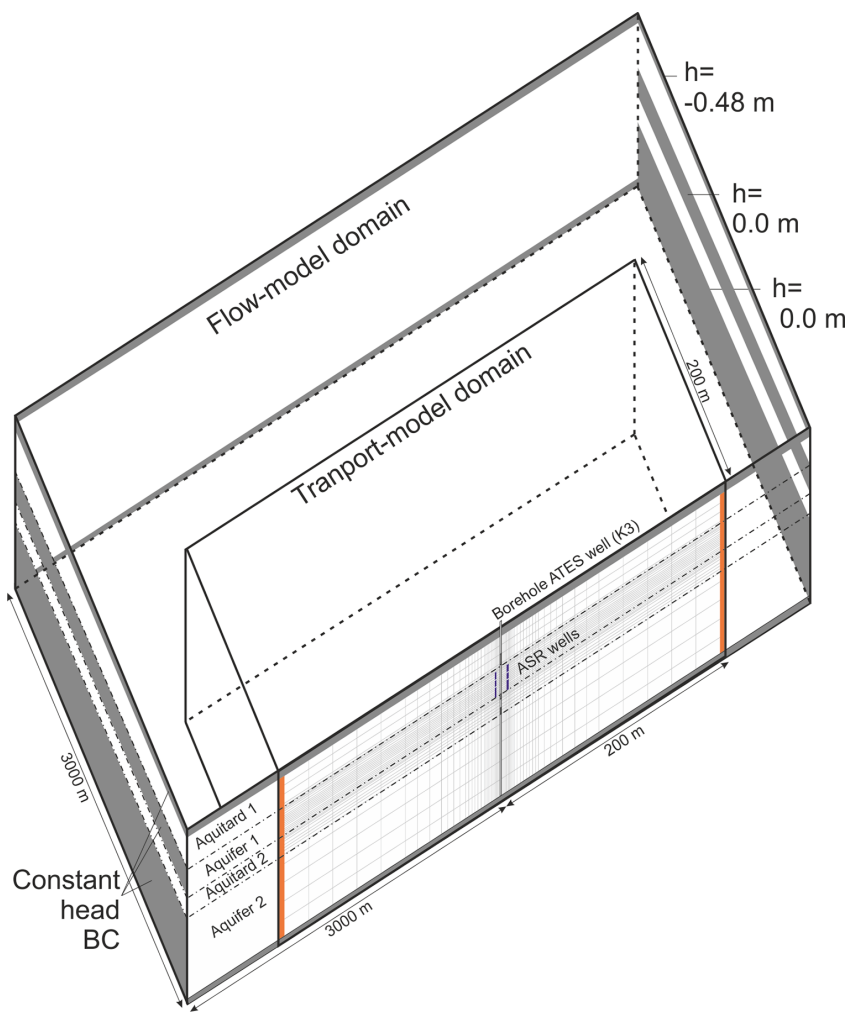

Figure 4. Setup of the Westland ASR groundwater transport model (half-domain).

the recovery had to be ceased due to the increased salinity. During this last salinization, the water at the deep (S3-)levels of the target aquifer at AW1, MW1, and MW2 showed low$\mathrm{SO}_{4}$ concentrations, indicating salinization by saltwater from Aquifer 1 instead of deep saltwater from Aquifer 2. High$\mathrm{SO}_{4-}$ concentrations $\left(>100 \mathrm{mg} \mathrm{L}^{-1}\right)$ were only found close to the K3-b ATES well (the presumable conduit) in this phase (AW1 and K3-bO1).

The SEAWAT model with leakage via the borehole of K3$\mathrm{b}$ was able to reasonably simulate the water quality trends regarding $\mathrm{SO}_{4}$ and $\mathrm{Cl}$ in Cycle 2 (Figs. 9 and 10). Remaining deviations in observed concentrations were contributed to uncertainties in the model input, mainly aquifer heterogeneity, potential stratification of the groundwater quality in Aquifer 2, and disturbing abstractions and injections in the surroundings, mainly by nearby ATES and brackish water reverse osmosis systems, the latter abstracting from Aquifer 1 and injecting in Aquifer 2.

Modeling of Cycle 2 demonstrated that salinization during recovery was independent of the injected freshwater volume. Salinization occurred after recovery with the same rate as in Cycle 1, despite a 4 times larger injection volume. Analysis of the modeled concentration distribution and pressure heads showed that injected freshwater could not reach deep into the deeper saline aquifers since the freshwater head in the leaky ATES borehole during injection was more or less equal to 
Table 6. Calculated leakage flux $Q_{\mathrm{VGP}}$ via the (unsealed) borehole based on Maas (2011) for different net recovery rates ( $Q_{\text {recovery, net }}$.

\begin{tabular}{llrrr}
\hline & & $\begin{array}{r}\text { Storage } \\
\text { (no recovery) }\end{array}$ & $\begin{array}{r}\text { Low } \\
\text { recovery rate }\end{array}$ & $\begin{array}{r}\text { High } \\
\text { recovery rate }\end{array}$ \\
\hline$Q_{\text {recovery, net }}$ & $\left(\mathrm{m}^{3} \mathrm{~d}^{-1}\right)$ & 0 & 77 & 371 \\
$\Delta \mathrm{h}_{\mathrm{GP}}$ & $\left(\mathrm{m}^{3}\right)$ & 0.15 & 0.30 & 0.66 \\
$Q_{\mathrm{VGP}}$ & $\left(\mathrm{m}^{3} \mathrm{~d}^{-1}\right)$ & 49 & 99 & 215 \\
$\mathrm{~W}$ & $\left(\mathrm{~m}^{2} \mathrm{~d}^{-1}\right)$ & 0.0031 & 0.0031 & 0.0031 \\
$\alpha$ & & 4.7 & 4.7 & 4.7 \\
$r_{0}$ & $(\mathrm{~m})$ & 0.1 & 0.1 & 0.1 \\
$r_{1}$ & $(\mathrm{~m})$ & 0.4 & 0.4 & 0.4 \\
$K_{\mathrm{HIN}}$ & $\left(\mathrm{m} \mathrm{d}^{-1}\right)$ & 100 & 100 & 100 \\
$K_{\mathrm{VIN}}$ & $\left(\mathrm{m} \mathrm{d}^{-1}\right)$ & 100 & 100 & 100 \\
$K_{\mathrm{VGP}}$ & $\left(\mathrm{m} \mathrm{d}^{-1}\right)$ & 1000 & 1000 & 1000 \\
\hline
\end{tabular}

the freshwater head in the deeper saltwater aquifer. In other words, little freshwater was pushed through the conduit into the deeper aquifer. Further on, the freshwater that did reach the deeper aquifer got rapidly displaced laterally as a result of buoyancy effects (Fig. 11).

A significant head difference $(\Delta h($ fresh $)=0.3$ to $0.65 \mathrm{~m})$ was observed in the model during recovery. In combination with the high permeability of the ATES borehole, this resulted in a significant intrusion of deeper $\left(\mathrm{SO}_{4}\right.$-rich) saltwater. Even during storage phases, a freshwater head difference $(\Delta h($ fresh $)=0.15 \mathrm{~m})$ was observed as a consequence of replacement of saltwater by freshwater in the target aquifer, causing intrusion of deep saltwater, yet with a lower rate than during recovery.

\subsection{Analysis of the leakage flux via the borehole}

An analytical solution was presented by Maas (2011) to calculate the vertical leakage via a gravel or sand pack. In this solution, it is presumed that an aquitard was pierced during drilling and the annulus was filled up with sand or gravel without installing a clay seal. The leakage is then calculated as function of the different hydraulic conductivities, pressure difference, and the radius of the borehole and well screen:

$Q_{\mathrm{VGP}}=\frac{\Delta h_{\mathrm{GP}}}{W}$,

where $Q_{\mathrm{VGP}}=$ vertical leakage via gravel pack $\left(\mathrm{m}^{3} \mathrm{~d}^{-1}\right)$, $\Delta h_{\mathrm{GP}}=$ hydraulic head difference between two sections of the gravel pack, one being the inflow and the other the outflow section (meters), and $W=$ leakage resistance $\left(\mathrm{d} \mathrm{m}^{-2}\right)$ and is calculated as

$W \approx \frac{\left(0.005(\ln (\alpha))^{2}-0.058 \ln (\alpha)+0.19\right)}{\left(r_{1} \sqrt{K_{\mathrm{HIN}} K_{\mathrm{VIN}}}\right)}$

and $a$ as

$\alpha=\frac{K_{\mathrm{VGP}}\left(r_{1}^{2}-r_{0}^{2}\right)}{2 K_{\mathrm{VIN}} r_{1}^{2}} /$, where $r_{0}=$ radius of well screen $(\mathrm{m}), r_{1}=$ radius of borehole $(\mathrm{m}), K_{\mathrm{VGP}}=$ vertical hydraulic conductivity of gravel pack $\left(\mathrm{m} \mathrm{d}^{-1}\right), K_{\mathrm{VIN}}=$ vertical hydraulic conductivity of inflow aquifer layer $\left(\mathrm{m} \mathrm{d}^{-1}\right)$, and $K_{\mathrm{HIN}}=$ horizontal hydraulic conductivity of the inflow aquifer layer $\left[\mathrm{m} \mathrm{d}^{-1}\right]$.

Calculating the leakage flux using the $\Delta h_{\mathrm{GP}}$ from the SEAWAT model underlines that the pressure differences induced by density differences and enhanced during abstraction for freshwater recovery in combination with an unsealed borehole leads to a saltwater intrusion $\left(Q_{\mathrm{VGP}}\right)$ of around 50 to $200 \mathrm{~m}^{3} \mathrm{~d}^{-1}$ (Table 6), which is in line with the observed leakage flux in the SEAWAT model.

\subsection{The maximal recovery efficiency with and without leakage at the Westland ASR site.}

The SEAWAT model was used to evaluate the ASR performance at the Westland field site with three different ASR strategies (Table 7), with and without the saltwater leakage. During the 120 days of recovery it was aimed to recover as much of the freshwater (marked by $\mathrm{Cl}<50 \mathrm{mg} \mathrm{L}^{-1}$ ) as possible. Equal abstraction rates were maintained for both ASR wells (AW1 and AW2) in the scenarios without leakage, whereas only AW2 was used for recovery in the scenarios with leakage.

Recovery with conventional, fully penetrating ASR wells will be limited to around $30 \%$ of the injected freshwater in a case without the saltwater leakage. For the case with leakage, freshwater recovery will be impeded by the shortcircuiting during the storage phase; the wells will produce brackish water already at the start of the recovery phase. The use of a MPPW for deep injection and shallow recovery has a limited positive effect due to the limited thickness of the aquifer: one-third of the injected water can be recovered in a case without leakage. The improvement of recovery efficiency (RE) by introduction of the MPPW is limited in comparison with the conventional ASR well since some saltwater from Aquitard 2 was found to move up to the shallower recovery wells of the MPPW system ("upconing") rapidly after 
Table 7. Modeled recovery efficiencies at the Westland ASR site without short-circuiting using different pumping strategies. The relative pumping rate per MPPW well screen is given for each particular screen.

\begin{tabular}{|c|c|c|c|}
\hline Strategy & Distribution pumping rate & $\begin{array}{l}\text { RE } \\
\text { (short-circuiting/no } \\
\text { short-circuiting) }\end{array}$ & $\begin{array}{l}\text { Intercepted brackish-saline } \\
\text { water (via deep (S3-)wells) }\end{array}$ \\
\hline Conventional ASR well & $\begin{array}{l}\text { In: } 100 \% \text { via one fully penetrating well } \\
\text { Out: } 100 \% \text { via one fully penetrating } \\
\text { well }\end{array}$ & $\begin{array}{l}\text { Year 1: } 0 / 15 \% \\
\text { Year 2: } 0 / 25 \% \\
\text { Year 3: } 0 / 30 \% \\
\text { Year 4: } 0 / 32 \%\end{array}$ & \\
\hline $\begin{array}{l}\text { Deep injection, shallow re- } \\
\text { covery (MPPW-ASR) }\end{array}$ & $\begin{array}{l}\text { In: } 10 / 20 / 70 \%(\text { Year } 1) \\
\text { In : 0/20/80\% (Year 2-3) } \\
\text { Abstract: } 60 / 40 / 0 \%(\text { Year } 1-3)\end{array}$ & $\begin{array}{l}\text { Year 1: } 1 / 19 \% \\
\text { Year 2: } 1 / 29 \% \\
\text { Year 3: } 1 / 32 \% \\
\text { Year 4: } 1 / 33 \%\end{array}$ & \\
\hline $\begin{array}{l}\text { MPPW- } \\
\text { ASR + "Freshkeeper" }\end{array}$ & $\begin{array}{l}\text { In: } 10 / 20 / 70 \% \text { (Year } 1 \text { ) } \\
\text { In : } 0 / 20 / 80 \% \text { (Year } 2 \text { ) } \\
\text { Abstract: Decreasing from 60/40/0 \% to } \\
60 / 0 / 0 \% \text { (Year } 1-3 \text { ) } \\
\text { Intercept Freshkeeper: increasing from } \\
100 \text { to } 500 \mathrm{~m}^{3} \mathrm{~d}^{-1}\end{array}$ & $\begin{array}{l}\text { Year 1: } 29 / 40 \% \\
\text { Year 2: } 32 / 46 \% \\
\text { Year 3: } 33 / 47 \% \\
\text { Year 4: } 33 / 48 \%\end{array}$ & $\begin{array}{l}\text { Year 1: } 32700 / 18500 \mathrm{~m}^{3} \\
\text { Year 2: } 33000 / 20500 \mathrm{~m}^{3} \\
\text { Year 3: } 31900 / 21500 \mathrm{~m}^{3} \\
\text { Year 4: } 31500 / 19300 \mathrm{~m}^{3}\end{array}$ \\
\hline
\end{tabular}

the start of recovery. The slight increase in $\mathrm{Cl}$ concentrations caused by this process is sufficient to terminate the recovery due to exceedance of the salinity limit. Before the fringe of the freshwater bubble reached the recovery wells, recovery was already terminated. In the case of saltwater leakage, salinization occurred within 2 days, limiting the RE to only $1 \%$.

The introduction of the Freshkeeper to protect the shallow recovery wells by interception of this deeper saltwater significantly extended the recovery period, enabling recovery of $40 \%$ in the first year for direct use. Ultimately, this will yield a RE of almost $50 \%$ of virtually unmixed $\left(\mathrm{Cl}<50 \mathrm{mg} \mathrm{L}^{-1}\right)$ injected freshwater in cycle 4 in a case without leakage. This will require interception of $18500 \mathrm{~m}^{3}$ (cycle 4) to $21500 \mathrm{~m}^{3}$ of brackish-saline groundwater, such that almost $30000 \mathrm{~m}^{3}$ of freshwater can be recovered.

When this ASR operational scheme with the Freshkeeper was applied to the field pilot, where short-circuiting saltwater hampered freshwater recovery, approximately one-third of the injected freshwater could be recovered. The ASR well close to the leaking borehole (AW1) was unable to abstract freshwater in this case. Only AW2 could be used for freshwater recovery, in the end only via the shallowest well (AW2S1). The freshwater loss by short-circuiting cannot be eliminated completely since a large volume of unmixed freshwater is abstracted together with intruding saltwater during the required interception. The RE will therefore remain lower than in an undisturbed geological setting (RE: $48 \%$ ). At the same time, the required interception of brackish-saline water will be higher (Table 7), with a total volume of more than $30000 \mathrm{~m}^{3}$, while around $20000 \mathrm{~m}^{3}$ of freshwater is recovered.

\section{Discussion}

\subsection{Saltwater intrusion during the Westland ASR pilot}

In this study, the first focus was on the causes for the significantly lower observed freshwater RE of the system. This RE was initially less than a few percent, whereas recovery of around one-third of the injected water was expected. The hydrochemical analyses clearly indicated that the observed salinization was caused by unexpected intrusion of deeper saltwater, as marked by substantially higher $\mathrm{SO}_{4}$ concentrations, which could not be caused by arrival of saltwater from the target aquifer or the upper aquitard, or by the $\mathrm{SO}_{4}$ release upon oxidation of pyrite in the target aquifer. The high$\mathrm{SO}_{4}$ concentrations also exclude early salinization by larger buoyancy effects than initially expected, for instance by a higher $K$ or higher ambient salinities in the target aquifer. The high- $\mathrm{SO}_{4}$ concentrations also excluded rapid lateral drift of injected water, as this would also have led to salinization by saltwater with low- $\mathrm{SO}_{4}$ concentrations. Additionally, lateral drift would also result in limited REs after addition of the Freshkeeper, which was not the case.

Knowing the source of the salinization, several transport routes can be presumed. First of all, intrusion of deep saltwater may occur when Aquitard 2 has a significantly lower $K$ than derived from grain size analyses, despite the distinct groundwater qualities observed. A more diffuse salinization via Aquitard 2 can then be expected. However, this salinization would be more gradual and better distributed around the wells. It would also mean that Aquitard 2 would quickly freshen during injection and salinize first during recovery. However, the later salinization of Aquitard 2 observed at 


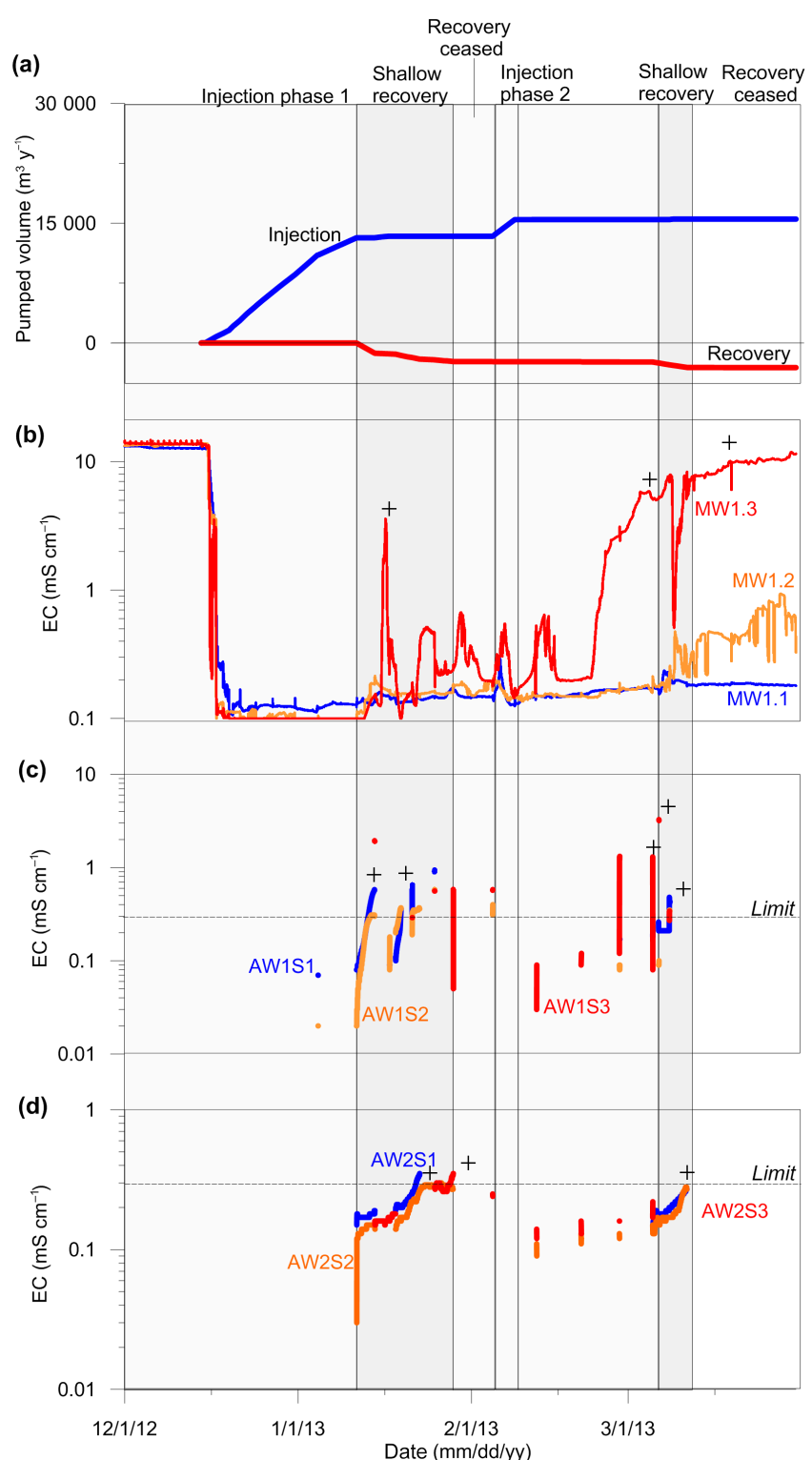

Figure 5. Pumping of the ASR system during cycle 1 (2012/2013), EC observations at MW1 (5 m from AW1), and the EC in the recovered water at AW1 and AW2. MW = monitoring well, $\mathrm{AW}=\mathrm{ASR}$ well.

MW1S4 with respect Aquifer 1 (observed at MW1S3 and K3-bO1) indicated that Aquitard 2 is bypassed by deeper saltwater during recovery. The presence of (a) conduits therefore provide (a) probable pathways for bypassing saltwater, meaning short-circuiting was occurring between Aquifers 1 and 2. The SEAWAT model underlines that this can indeed explain the early and rapid intrusion by deep saltwater. Since the highest $\mathrm{Cl}$ and $\mathrm{SO}_{4}$ concentrations were found in the borehole of $\mathrm{K} 3-\mathrm{b}$ well (K3-bO1), this borehole provides the most presumable location of (a) conduits. Natural conduits are considered unlikely due to continuity and thickness of Aquitard 2 observed in the surrounding of the ASR wells and

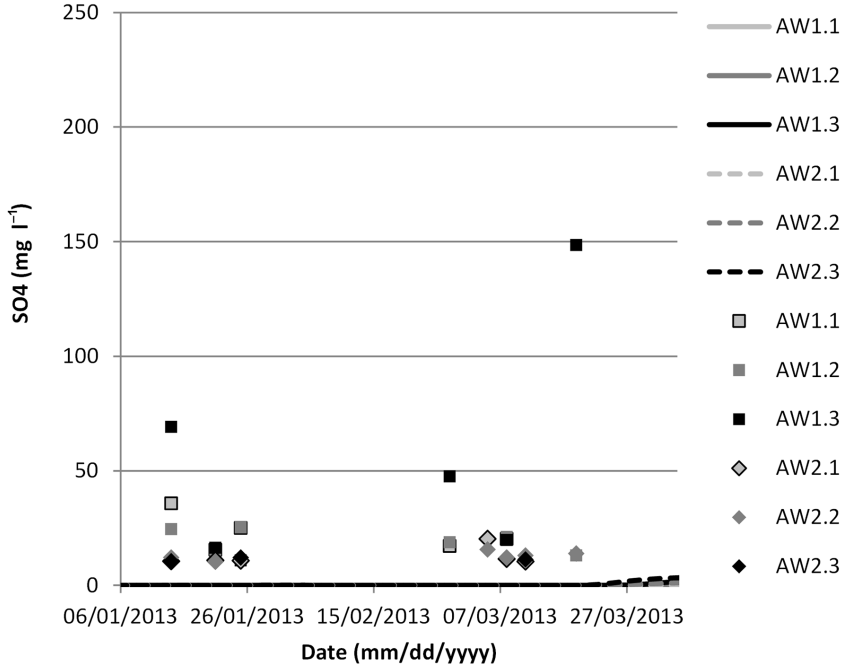

Figure 6. Modeled (solid lines) and observed (data points) $\mathrm{SO}_{4}$ concentrations without borehole leakage. High concentrations indicate admixing of deeper saltwater. Observed $\mathrm{SO}_{4}$ concentrations by far exceed the modeled concentrations.

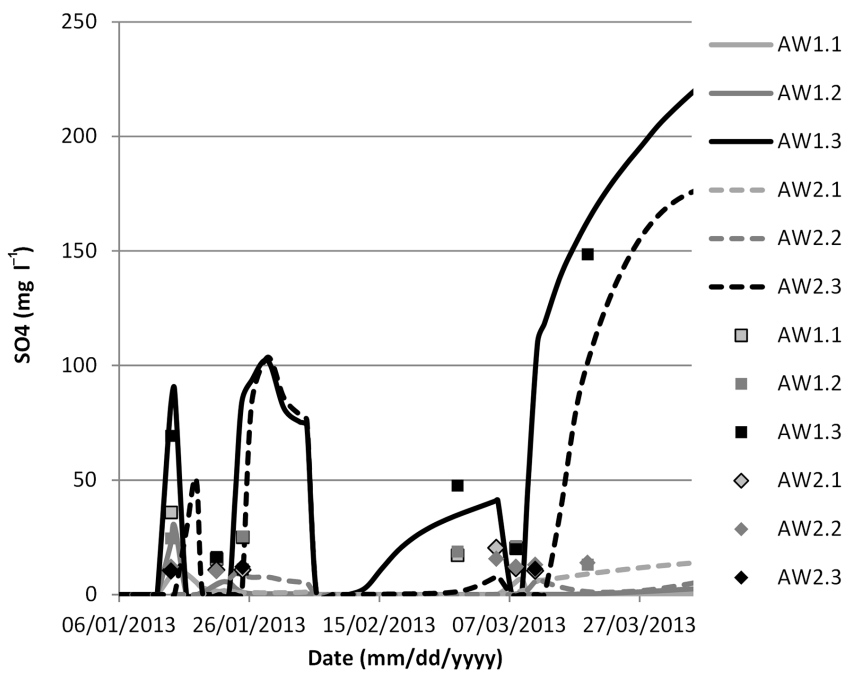

Figure 7. Modeled (solid lines) and observed (data points) $\mathrm{SO}_{4}$ concentrations. Borehole leakage at the location of the current ATES $\mathrm{K} 3$ well via a $1 \mathrm{~m} \times 1 \mathrm{~m}$ borehole with $K=1000 \mathrm{~m} \mathrm{~d}^{-1}$. High concentrations indicate admixing of deeper saltwater. Observed $\mathrm{SO}_{4}$ concentrations become in line with the modeled concentrations.

the geological genesis (unconsolidated, horizontal lagoonal deposits). The conduits at or around the K3-b borehole may originate from the time of installation (improper sealing) or operation, as recorded operation data of the ATES system reports that incidentally exceeded the maximum injection pressure in the well of 1 bar during maintenance in 2009. 


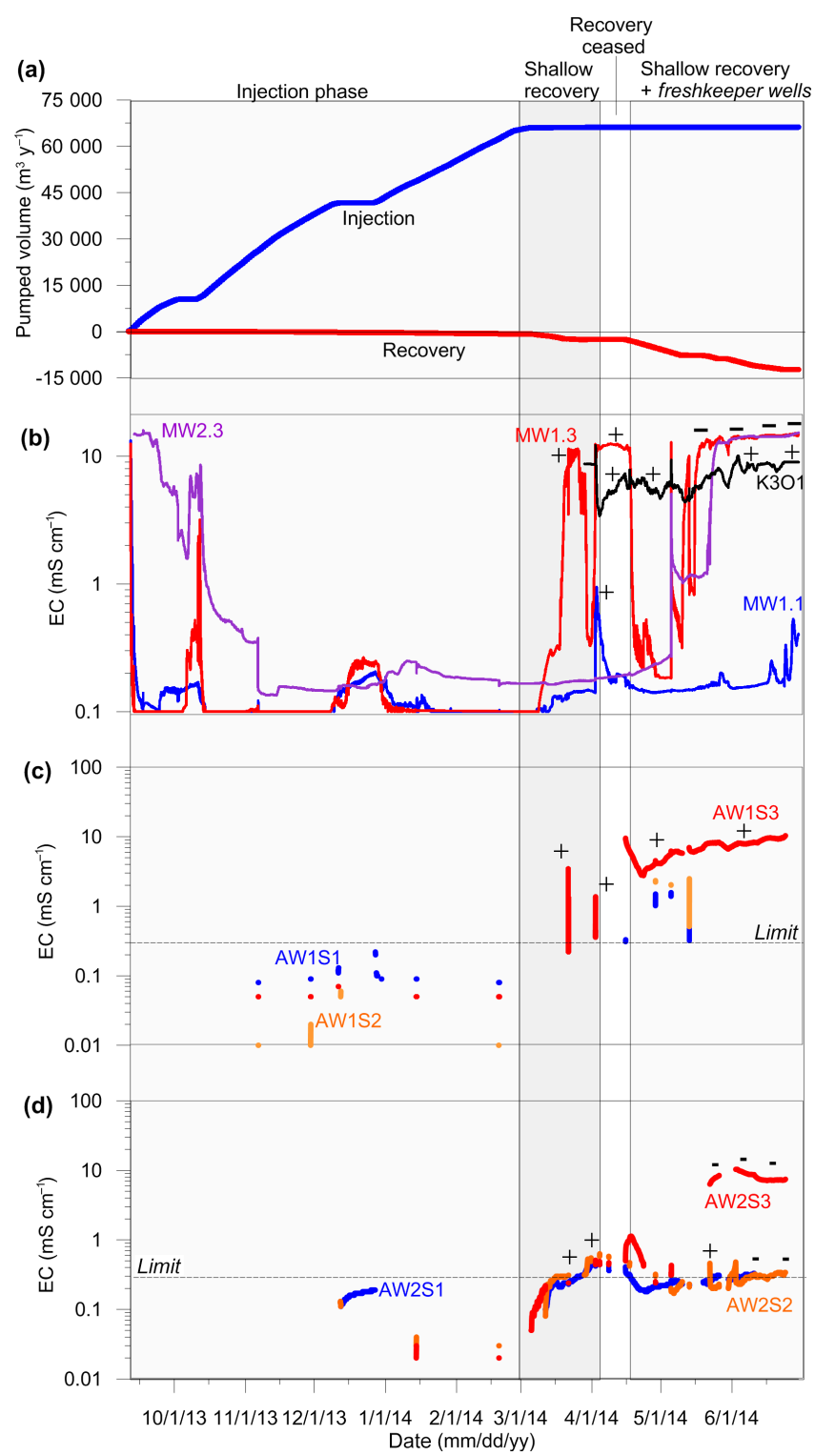

Figure 8. Pumping of the ASR system during cycle 2 (2013/2014), EC observations at MW1 (5 m from AW1), and the EC in the recovered water at AW1 and AW2. AW2.1 and AW2.3 were used for freshwater recovery $\left(12324 \mathrm{~m}^{3}\right)$. Presence of increased $\mathrm{SO}_{4}$ concentrations (deep saltwater) are marked by “+”, while its absence is marked by "-" (indicating shallow saltwater).

\subsection{The consequences of short-circuiting on ASR in coastal aquifers}

The potential effects of short-circuiting induced by deep perturbation on ASR in a shallower coastal aquifer were subsequently explored. In this case of freshwater storage in a confined, saline aquifer, pressure differences induced by the difference in density between injected freshwater, and native groundwater provoked intrusion of native groundwater in the injected freshwater bubbles via the presumed conduit. It is illustrated that a complete failure of the ASR system can occur when the short-circuiting via such a conduit occurs close to the ASR wells and little mixing with ambient saltwater is allowed.

The negative effects of short-circuiting on ASR on coastal aquifers are mainly related to the hydraulics around the conduits. First, freshwater is not easily transported downwards through the conduits into a deeper aquifer, while it is easily pushed back into the shallower aquifer when injection is stopped or paused. Second, the freshwater reaching a deeper aquifer is subjected to buoyancy effects and migrates laterally in the top zone of this deeper aquifer. Finally, during storage and especially during recovery, the pressure differences in combination with a high hydraulic conductivity rapidly induce a strong flux of saltwater from the whole deeper aquifer into the shallower ASR target aquifer, where a relatively low hydraulic head is present. This short-circuiting induced by such a pressure difference is hampered by the low permeability of the aquitard in a "pristine situation". A continuous, undisturbed aquitard is therefore indispensable for the success of ASR in such a setting, as intrusion of deeper saltwater is not desired.

With an increasing distance between the ASR wells and a nearby conduit, the proportion of mixed saltwater in the recovered water decreases while the arrival time increases. When the conduit is situated outside the radius of the injected freshwater body in the target aquifer, a decrease in RE is not expected.

The Westland field example highlights how design, installation, and operational aspects are vital in the more-and-and more exploited subsurface in densely populated areas. First of all, old boreholes are unreliable and their presence should better be avoided when selecting new ASR well sites (Maliva et al., 2016). Second, installation and operation of (especially injection) wells should be regulated by strict protocols to prevent the creation of new pathways for short-circuiting. Finally, it is important to recognize that similar processes may occur in unperturbed coastal karst aquifers, where natural vertical pipes can be present (Bibby, 1981; Missimer et al., 2002).

\subsection{Mitigation of short-circuiting on ASR in coastal aquifers}

In order to mitigate the short-circuiting and improve the freshwater recovery upon aquifer storage under these unfavorable conditions, several strategies can be recognized. $\mathrm{Ob}$ viously, sealing of the conduits would be an effective remedy. However, it may not be viable to (1) locate all conduits, for instance when the former wells are decommissioned or when the confining clay layer is fractured upon deeper injection under high pressure, and (2) successfully seal a conduit at a great depth. This is underlined by the fact that only limited reports of successful sealing of deep conduits can be found. 

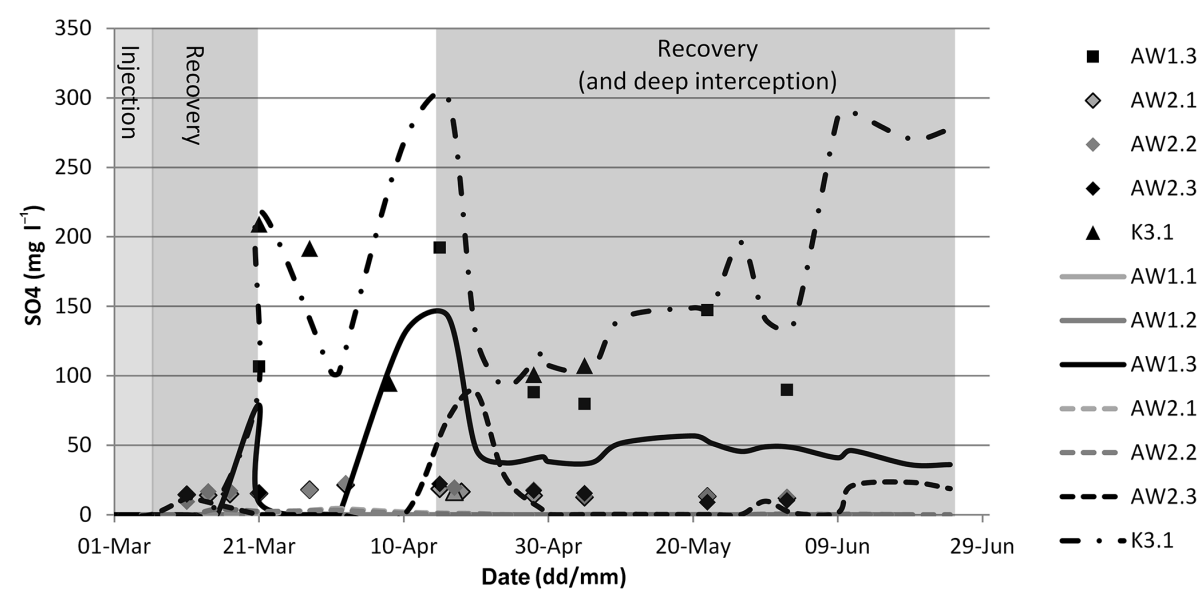

Figure 9. Modeled and observed $\mathrm{SO}_{4}$ concentrations at the most relevant well screens.

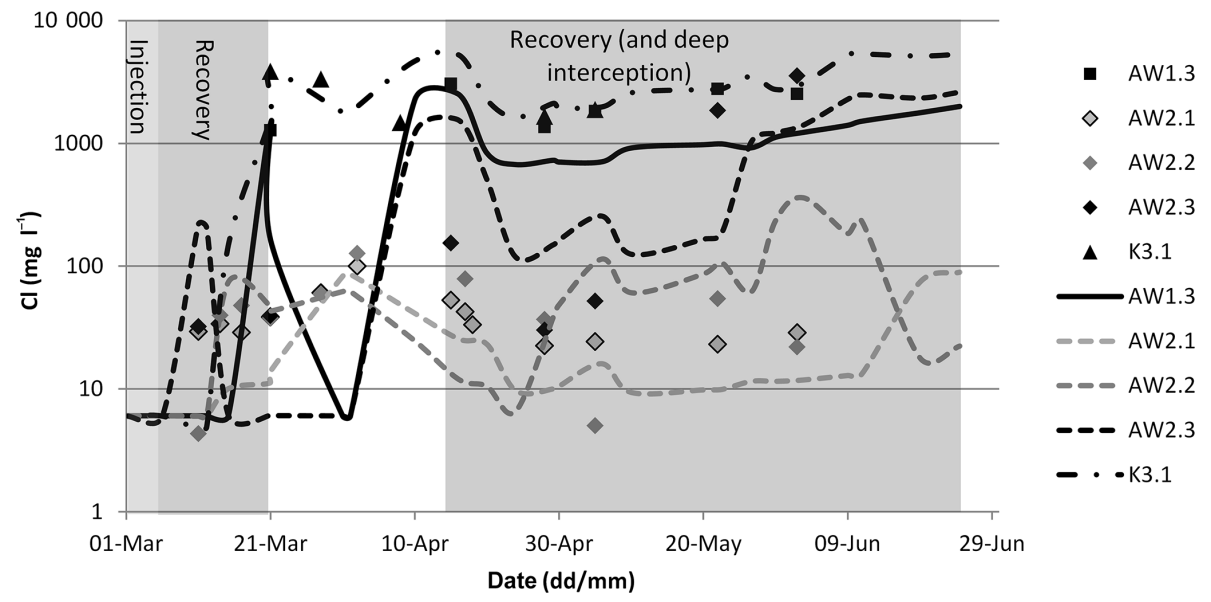

Figure 10. Modeled and observed $\mathrm{Cl}$ concentrations at the most relevant well screens.

Apart from sealing, one can also try to deal with these unfavorable conditions. MPPW were installed at the Westland ASR site, for instance, enabled interception of intruding saltwater by using the deeper well screens as "Freshkeepers". After this intervention, about one-third of virtually unmixed injected freshwater becomes recoverable. This way, the RE is brought to a level similar to the level obtained by an MPPWequipped ASR system without the Freshkeeper interception and without short-circuiting, while the RE would otherwise remain virtually null. It does require interception of a significant volume of brackish-saline groundwater, however, which must be injected elsewhere or disposed of. The addition of a Freshkeeper will therefore inevitably increase the investment costs (additional infrastructure for re-injection/disposal) and operational costs (electricity required for pumping).

A significant part of the unmixed freshwater is blended with saltwater in the Freshkeeper wells, such that the freshwater recovery becomes lower than in the situation in which the Freshkeeper is applied and saltwater intrusion via short- circuiting is absent. At the Westland field site, this is compensated by desalinating the intercepted brackish-saline groundwater, which is a suitable source water for reverse osmosis (RO) thanks to its low salinity. The freshwater (permeate) produced in this process is used for irrigation, while the resulting saltwater (concentrate) is disposed of in Aquifer 2. The resulting RE increase is plotted in Fig. 12. Even when no unmixed freshwater is available, desalination of injected water mixed with groundwater can be continued with this technique to further increase the RE. In comparison with conventional brackish water RO, this leads to a better feed water for RO (lower salinity) while salinization of the groundwater system by a net extraction of freshwater is prevented by balancing the freshwater injection and abstraction from the system. 


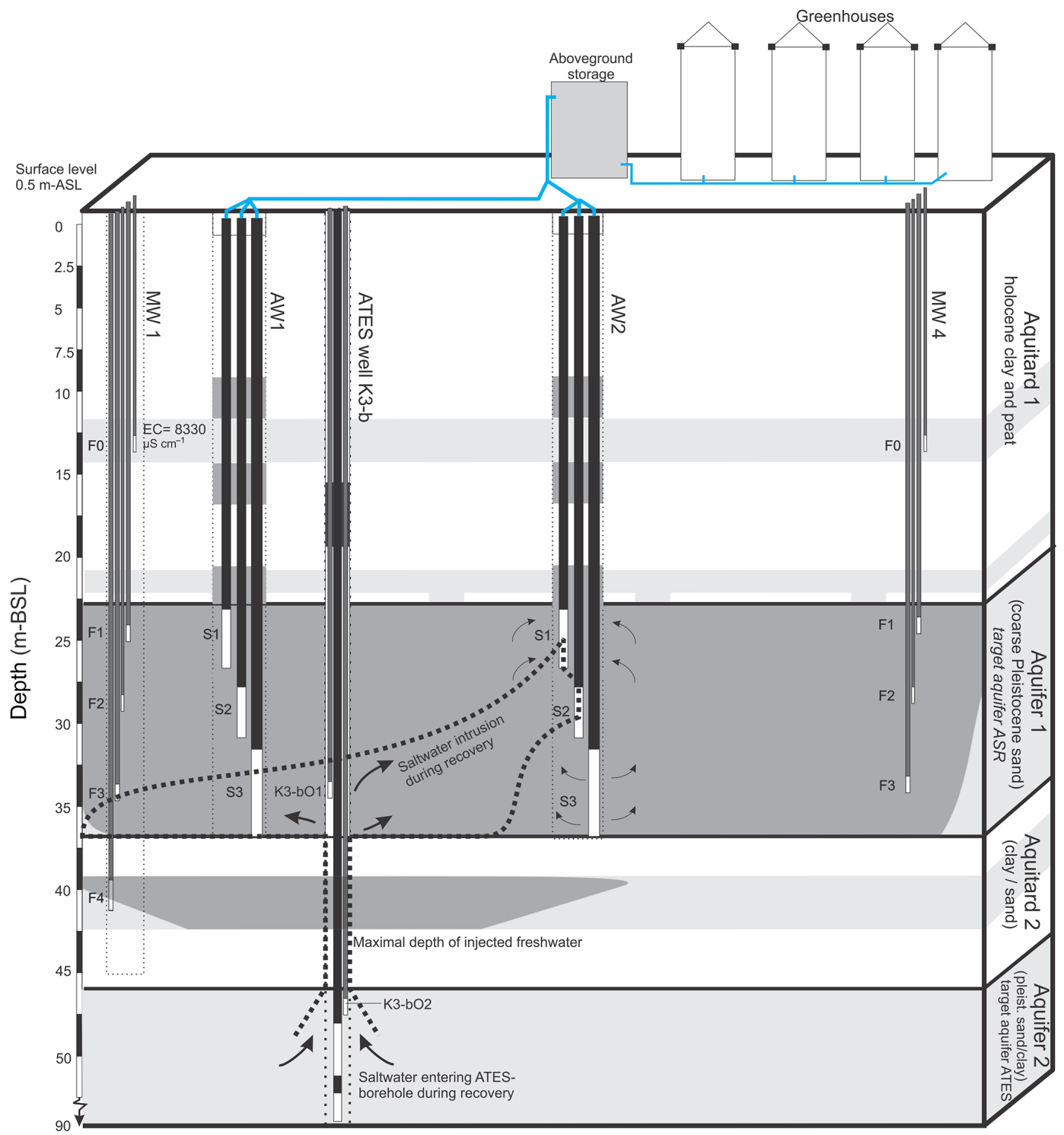

Figure 11. Deep saltwater intrusion via ATES K3-b borehole during shallow recovery of injected freshwater at the Westland ASR site at the start of Cycle 2 .

\subsection{On the performance of ASR in coastal aquifers without leakage: upconing brackish water from the deeper aquitard}

In case of a strict water quality limit and relatively saline groundwater, brackish groundwater upconing from the deeper confining aquitard toward shallow recovery wells is a process to take into account, apart from the buoyancy effects in the target aquifer itself. This was shown by the SEAWAT model runs without short-circuiting, which showed a small increase in $\mathrm{Cl}$ concentrations at the ASR wells prior to the full salinization caused by arrival of the fringe of the ASR bubble. The SEAWAT model indicated that the (sandy) clay/peat layer (Aquitard 2) below the target aquifer was the source of upconing brackish-saline groundwater. Although this layer has a low hydraulic conductivity, it is not impermeable and salinization via diffusion can occur in this zone, while brackish pore water can physically be extracted from this aquitard. The transport processes in this deeper aquitard are comparable with the borehole leakage water via conduits in this aquitard: freshwater is not easily pushed downwards during injection, but brackish water is easily attracted during recovery. After the recovery phase this zone salinizes until the next injection phase starts, so a gradual improvement in time is limited. Brackish water may also be attracted from the upper aquitard ("downconing"), but this process is counteracted by the buoyancy effects and did not lead to early termination of the freshwater recovery in the Westland case. 


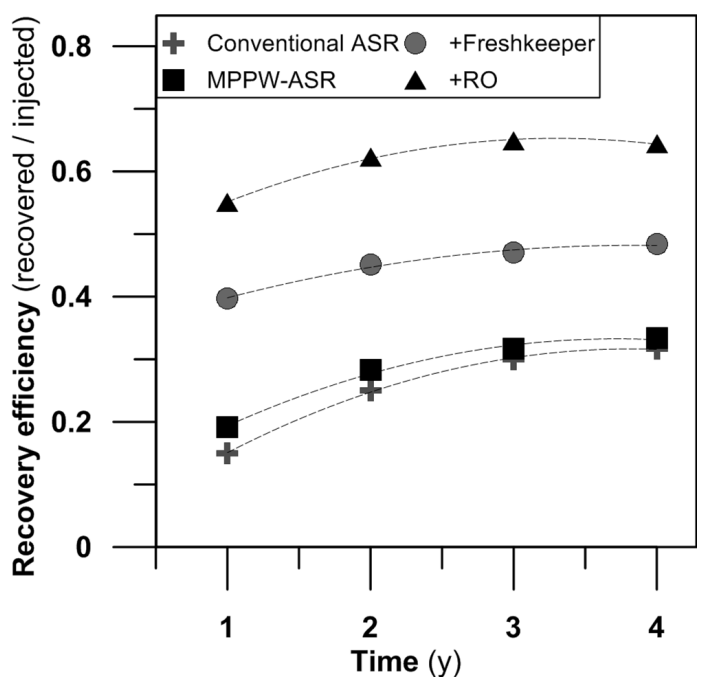

Figure 12. Recovery efficiencies at the Westland ASR site with and without the borehole leakage resulting from the SEAWAT groundwater transport model for a conventional ASR well (one well screen, fully penetrating), deep injection and shallow recovery via multiple partially penetrating wells without a "Freshkeeper" (scenario MPPW), for a MPPW in combination with a "Freshkeeper" (scenario Freshkeeper), and for a scenario in which RO is applied on the intercepted brackish water to produce additional freshwater $(50 \%$ of the abstracted brackish water).

The release of brackish water from the deeper aquitard in coastal aquifers can be relevant when quality limits are strict, the native groundwater is saline, and the native groundwater in the target aquifer is displaced far from the ASR wells. The performance of ASR may then be much worse than is predicted by existing ASR performance estimation methods (e.g., Bakker, 2010; Ward et al., 2009), which assume that impermeable aquitards confine the target aquifer. Even in the first MPPW field test (Zuurbier et al., 2014), this process was not observed, due to a smaller radius of the freshwater bubble, resulting in earlier salinization due to buoyancy effects. The upconing water can optionally be intercepted by a (small, deep) Freshkeeper well screen to extent the recovery of unmixed freshwater, likewise the interception of intruding saltwater at the Westland site.

Finally it should be noted that the ASR system analyzed in this study had very strict water quality limits (practically no mixing allowed) and that a buffer zone (Pyne, 2005) between the injected freshwater and the relatively saline ambient groundwater was not realized before starting the ASR cycles. The boundary conditions for ASR were therefore already unfavorable. Also, the potential improvement after more than three cycles was not explored. The performance of this ASR system should therefore not be considered the typical performance of ASR in a brackish-saline aquifers, which controlled by a complex interplay of geological conditions and operational parameters (Bakker, 2010), well design (Zu- urbier et al., 2014, 2015), and the formation of a buffer zone prior to starting the ASR cycles (Pyne, 2005).

\section{Conclusions}

This study shows how short-circuiting negatively affects the freshwater recovery efficiency (RE) during aquifer storage and recovery (ASR) in coastal aquifers. ASR was applied in a shallow saltwater aquifer (23-37 m b.s.l.) overlying a deeper saltwater aquifer (> $47.5 \mathrm{~m}$ b.s.l.) targeted for aquifer thermal energy storage. Intrusion of deeper saltwater was marked by chemical tracers (mainly $\mathrm{SO}_{4}$ ) and quickly terminated the freshwater recovery. The most presumable pathway was the borehole of an ATES well at $3 \mathrm{~m}$ from the ASR well (forming a conduit) and was identified by field measurements, hydrochemical analyses, and SEAWAT transport modeling. Transport modeling underlined that the potentially rapid shortcircuiting during storage and recovery can reduce the RE to null. This is caused by a rapid intrusion of the deep saltwater already during storage periods, and especially during recovery. Transport modeling also showed that when limited mixing with ambient groundwater is allowed, a linear RE decrease by short-circuiting with increasing distances from the ASR well within the radius of the injected ASR bubble is found. Old boreholes should therefore rather be avoided during selection of new ASR sites, or must be situated outside the expected radius.

Field observations and groundwater transport modeling showed that interception of deep short-circuiting water can mitigate the observed RE decrease, although complete compensation of the RE decrease will generally be unattainable since also unmixed freshwater gets intercepted. At the Westland ASR site, the RE can be brought back to around onethird of the injected water, which is comparable to the RE attained with an ASR system without the Freshkeeper in the same, yet undisturbed, setting. With the same Freshkeeper, the setup would be able to abstract around $50 \%$ of the injected water unmixed, if the setting would be undisturbed. This underlines the added value of such a interception well for ASR. Finally, it was found that brackish water upconing from the underlying aquitard towards the shallow recovery wells of the MPPW-ASR system can occur. In case of strict water quality limits, this process may cause an early termination of freshwater recovery, yet it was neglected in many ASR performance estimations to date.

\section{Data availability}

The data used in this manuscript can be obtained by contacting the authors.

Competing interests. The authors declare that they have no conflict of interest. 
Acknowledgements. The authors would like to thank the funding agents of the studies discussed in this paper: Knowledge for Climate, the Joint Water Research Program of the Dutch Water Supply Companies (BTO), the EU FP7 project "Demonstrate Ecosystem Services Enabling Innovation in the Water Sector" (DESSIN, grant agreement no. 619039), and the EU Horizon2020-project "SUBSOL" (grant agreement no. 642228).

Edited by: B. Berkowitz

Reviewed by: D. Pyne and one anonymous referee

\section{References}

Bakker, M.: Radial Dupuit interface flow to assess the aquifer storage and recovery potential of saltwater aquifers, Hydrogeol. J., $18,107-115,2010$.

Bakr, M., van Oostrom, N., and Sommer, W.: Efficiency of and interference among multiple Aquifer Thermal Energy Storage systems, A Dutch case study, Renew. Energ., 60, 53-62, 2013.

Bibby, R.: Mass transport of solutes in dual-porosity media, Water Resour. Res., 17, 1075-1081, 1981.

Bonte, M., Stuyfzand, P. J., Hulsmann, A., and Van Beelen, P.: Underground Thermal Energy Storage: Environmental Risks and Policy Developments in the Netherlands and European Union, Ecology and Society, 16, 2011a.

Bonte, M., Stuyfzand, P. J., Van den Berg, G. A., and Hijnen, W. A. M.: Effects of aquifer thermal energy storage on groundwater quality and the consequences for drinking water production: a case study from the Netherlands, Water Sci. Technol., 63, 19221931, 2011b.

Bonte, M., van Breukelen, B. M., and Stuyfzand, P. J.: Temperatureinduced impacts on groundwater quality and arsenic mobility in anoxic aquifer sediments used for both drinking water and shallow geothermal energy production, Water Res., 47, 5088-5100, 2013.

CBS: Hernieuwbare energie in Nederland 2012, CBS, available at: www.cbs.nl, last access: 24 November 2013.

Chesnaux, R.: Uncontrolled Drilling: Exposing a Global Threat to Groundwater Sustainability, Journal of Water Resource and Protection, 4, 746-749, 2012.

Chesnaux, R. and Chapuis, R.: Detecting and quantifying leakage through defective borehole seals: a new methodology and laboratory verification, Geotech. Test. J., 30, 1-7, 2007.

Chesnaux, R., Rafini, S., and Elliott, A.-P.: A numerical investigation to illustrate the consequences of hydraulic connections between granular and fractured-rock aquifers, Hydrogeol. J., 20, 1669-1680, 2012.

Chiang, E. W. H.: Processing Modflow: an integrated modeling environment for the simulation of groundwater flow, transport and reactive processes, Simcore Software, Irvine, USA, 2012.

Ferguson, B. K.: Urban storm water infiltration: Purposes, implementation, results, J. Soil Water Conserv., 45, 605-609, 1990.

Gasda, S., Nordbotten, J., and Celia, M.: Determining effective wellbore permeability from a field pressure test: a numerical analysis of detection limits, Environ. Geol., 54, 1207-1215, 2008.

Hubber, M. K. and Willis, D. G.: Mechanics of hydraulic fracturion, AAGP, Memoir, 18, 199-217, 1972.
Jiménez-Martínez, J., Aravena, R., and Candela, L.: The Role of Leaky Boreholes in the Contamination of a Regional Confined Aquifer. A Case Study: The Campo de Cartagena Region, Spain, Water Air Soil Poll., 215, 311-327, 2011.

Langevin, C. D., Thorne, D. T., Dausman, A. M., Sukop, M. C., and Guo, W.: SEAWAT version 4: a computer program for simulation of multi-species solute and heat transport, in: Techniques and Methods, edited by: U.S.G.S., book 6, Reston, Virginia, USA, 2007.

Leonard, B. P.: Universal limiter for transient interpolation modeling of the advective transport equations: the ULTIMATE conservative difference scheme, NASA Technical Memorandum 100916 ICOMP-88-11, 1988.

Ma, R. and Zheng, C.: Effects of density and viscosity in modeling heat as a groundwater tracer, Ground Water, 48, 380-389, 2010.

Maas, C.: Leakage via unsealed boreholes, KWR watercycle research institute, Nieuwegein, 2011 (in Dutch).

Maliva, R. G. and Missimer, T. M.: Aquifer Storage and Recovery and Managed Aquifer Recharge using wells; planning, hydrogeology, design and operation. Methods in Water Resources Evolution. Schlumberger, Texas, USA, 578 pp., 2010.

Maliva, R. G., Barnes, D., Coulibaly, K., Guo, W., and Missimer, T. M.: Solute-Transport Predictive Uncertainty in Alternative Water Supply, Storage, and Treatment Systems, Groundwater, 2016.

Missimer, T. M., Guo, W., Walker, C. W., and Maliva, R. G.: Hydraulic and density considerations in the design of aquifer storage and recovery systems, Florida Water Resources Journal, 55, 30-36, 2002.

Morris, B. L., Lawrence, A. R. L., Chilton, P. J. C., Adams, B., Calow, R. C., and Klinck, B. A.: Groundwater and its susceptiblity to degradation: A global assessment of the problem and options for management, United Nations Environment Programme, Nairobi, 2003.

Mos Grondmechanica: Interpretation pilot drilling for ATES system grower's association Prominent at Groeneweg-II, Mos Grondmechanica, Rotterdam, 2006.

Olsthoorn, T. N.: KIWA announcement 71: Clogging of injection wells, Keuringsinstituut voor waterartikelen, Niewegein, 1982 (in Dutch).

Pyne, R. D. G.: Aquifer Storage Recovery - A guide to Groundwater Recharge Through Wells, ASR Systems LLC, Gainesville, Florida, USA, 608 pp., 2005.

Richard, S., Chesnaux, R., Rouleau, A., Morin, R., Walter, J., and Rafini, S.: Field evidence of hydraulic connections between bedrock aquifers and overlying granular aquifers: examples from the Grenville Province of the Canadian Shield, Hydrogeol. J., 116, 2014.

Santi, P., McCray, J., and Martens, J.: Investigating crosscontamination of aquifers, Hydrogeol. J., 14, 51-68, 2006.

Steeneveldt, R., Berger, B., and Torp, T. A.: $\mathrm{CO}_{2}$ Capture and Storage: Closing the Knowing-Doing Gap, Chem. Eng. Res. Des., 84, 739-763, 2006.

Stichting Infrastructuur Kwaliteitsborging Bodembeheer: Protocol 2100 (version 3.1): Mechanical drilling, Stichting Infrastructuur Kwaliteitsborging Bodembeheer (SIKB), Gouda, 2013a (in Dutch).

Stichting Infrastructuur Kwaliteitsborging Bodembeheer: Protocol 11001: Design, realisation, and control of the subsurface elements of aquifer thermal energy storage systems, Stichting 
Infrastructuur Kwaliteitsborging Bodembeheer (SIKB), Gouda, 74 pp., 2013b (in Dutch).

Stuyfzand, P. J.: Hydrochemistry and Hydrology of the Coastal Dune area of the Western Netherlands, Vrije Universiteit, Amsterdam, the Netherlands, 366 pp., 1993.

Stuyfzand, P. and Raat, K.: Benefits and hurdles of using brackish groundwater as a drinking water source in the Netherlands, Hydrogeol. J., 18, 117-130, 2010.

TNO: Interpolated isohypses (28 April 1995), Utrecht, the Netherlands, available at: www.dinoloket.nl (last access: 15 October 2010), 1995.

Tsang, C.-F., Birkholzer, J., and Rutqvist, J.: A comparative review of hydrologic issues involved in geologic storage of $\mathrm{CO}_{2}$ and injection disposal of liquid waste, Environ. Geol., 54, 1723-1737, 2008.

Van Ginkel, M., Olsthoorn, T. N., and Bakker, M.: A New Operational Paradigm for Small-Scale ASR in Saline Aquifers, Groundwater, 52, 685-693, 2014.

Ward, J. D., Simmons, C. T., Dillon, P. J., and Pavelic, P.: Integrated assessment of lateral flow, density effects and dispersion in aquifer storage and recovery, J. Hydrol., 370, 83-99, 2009.

Zuurbier, K. G., Paalman, M., and Zwinkels, E.: Haalbaarheid Ondergrondse Waterberging Glastuinbouw Westland, KWR 2012.003, KWR Watercycle Research Institute, Nieuwegein, 2012.
Zuurbier, K., Bakker, M., Zaadnoordijk, W., and Stuyfzand, P.: Identification of potential sites for aquifer storage and recovery (ASR) in coastal areas using ASR performance estimation methods, Hydrogeol. J., 21, 1373-1383, 2013a.

Zuurbier, K. G., Hartog, N., Valstar, J., Post, V. E. A., and van Breukelen, B. M.: The impact of low-temperature seasonal aquifer thermal energy storage (SATES) systems on chlorinated solvent contaminated groundwater: Modeling of spreading and degradation, J. Contam. Hydrol., 147, 1-13, 2013 b.

Zuurbier, K. G., Zaadnoordijk, W. J., and Stuyfzand, P. J.: How multiple partially penetrating wells improve the freshwater recovery of coastal aquifer storage and recovery (ASR) systems: A field and modeling study, J. Hydrol., 509, 430-441, 2014.

Zuurbier, K. G., Kooiman, J. W., Groen, M. M. A., Maas, B., and Stuyfzand, P. J.: Enabling Successful Aquifer Storage and Recovery of Freshwater Using Horizontal Directional Drilled Wells in Coastal Aquifers, J. Hydrol. Eng., 20, B4014003, doi:10.1061/(ASCE)HE.1943-5584.0000990, 2015.

Zuurbier, K. G., Hartog, N., and Stuyfzand, P. J.: Reactive transport impacts on recovered freshwater quality during multiple partially penetrating wells (MPPW-)ASR in a brackish heterogeneous aquifer, Appl. Geochem., 71, 35-47, 2016. 